\title{
EDUCATION
}

\section{Mediation Effect of Locus of Control on the Causal Relationship between Students' Perceived Teachers' Expectancy and Self-Esteem}

\section{Kususanto Prihadi, Nizam Ismail Hairul \& Jamil Hazri}

${ }^{1}$ School of Educational Studies, Universiti Sains Malaysia

\section{Indonesia}

Correspondence: Ditto Prihadi Kususanto. School of Educational Studies, Universiti Sains Malaysia, 11800 USM, Penang, Malaysia. E-mail: personalitymagics@gmail.com

(C) Education \& Psychology I+D+i and Editorial EOS (Spain) 


\begin{abstract}
Introduction. Symbolic interaction theorists maintained that general self-esteem, defined as the way individuals assess themselves, is based on the individual's perception on the way others assess them (we are what we think other people think we are). Accordingly, studies in school settings indicated that students' perceived teachers' expectancy (PTE) affected students' self-esteem. In other words, evidence had shown that students who perceived that their teachers expected them to have high academic achievement would likely to have higher general self-esteem than students who perceived that their teachers expected them to perform low or to be involved in disciplinary matters. However, only handful of researches in school settings had focused on the role of locus of control (LoC) in the process of self-esteem development. Moreover, little research had focused on a school where only students with high-academic reports are accepted (High-performance schools), where they would not find lowachiever counterparts to be compared with. In the context of this study, students' internal LOC was taken as a mediating variable between PTE and self-esteem.
\end{abstract}

Method. Eight hundred participants were given three sets of questionnaires including Rosenberg SelfEsteem Scale, Internal Control Index, and Perception of Teachers' Behavior Scale. In order to analyze the data, statistical method of One-Way ANOVA was employed. The software of SPSS was utilized in order to analyze and produce the result tables.

Results. The results showed that the students' LoC mediated the influence of their PTE on their selfesteem. In other words, while symbolic interaction theory explained that self-esteem development among students is highly affected by PTE, findings of this research added that the contribution of PTE on self-esteem is mediated by LoC.

Discussion and Conclusion. When students believe that their events are caused by their own effort (having internal LoC instead of external LoC), their PTE will not affect their self-esteem. While internal LoC is related to responsibility, it is possible to protect students' self-esteem from negative influence of PTE by improving their sense of responsibility, which then leads them to have internal LoC. Furthermore, follow-up research in improving internal LoC is suggested. Further practical implications of the findings are discussed at the end of the paper.

Keywords: High-Performing Students, Locus of Control, Perceived Teachers' Expectancy, SelfEsteem, Symbolic Interaction Theory, Two-dimensional model of self-esteem.

Received: 04/21/11 Initial acceptance: 06/15/12 Final acceptance: 07/04/12 


\section{Efecto mediador del locus de Control en la relación causal entre percepción de los alumnos de la expectación docente y su autoestima. Resumen}

Introducción. Teóricos de la interacción simbólica han sostenido que la autoestima general, definida como la forma como los individuos evaluar por sí mismas, se basa en la percepción del individuo sobre la manera en que otros a evaluar (somos lo que pensamos que otra gente piensa que somos). En consecuencia, los estudios en los centros escolares indicó que la esperanza de los profesores perciben los estudiantes (TEP) afectó a los estudiantes la autoestima. En otras palabras, la evidencia ha demostrado que los estudiantes que perciben que sus profesores se espera que tengan un alto rendimiento académico probablemente a tener una mayor autoestima general que los estudiantes que perciben que sus profesores se espera que realicen bajo o de participar en los procedimientos disciplinarios asuntos. Sin embargo, sólo un puñado de investigaciones en el ámbito escolar se ha centrado en el papel de locus de control (LOC) en el proceso de desarrollo de la autoestima. Por otra parte, pocas investigaciones se habían centrado en una escuela donde los estudiantes sólo con académicos de alto los informes son aceptados (escuelas de alto rendimiento), en el que no se encuentran bajo cumplidor contrapartes para ser comparados con. En el contexto de este estudio, los estudiantes internos LOC fue tomada como una variable mediadora entre el PTE y la autoestima.

Método. Se les dio a ochocientos participantes tres tipos de cuestionarios incluidos los de Autoestima de Rosenberg, índice de Control Interno, y la percepción de la escala de comportamiento de los maestros. Con el fin de analizar los datos, el método estadístico de ANOVA de un sentido fue empleado. El software SPSS fue utilizado con el fin de analizar y elaborar las tablas de resultados.

Resultados. Los resultados mostraron que el lugar de control de los estudiantes medió la influencia de su PTE en su autoestima. Mientras que la teoría de la interacción simbólica explicó que el desarrollo de la autoestima entre los estudiantes se ve muy afectada por el PTE, las conclusiones de esta investigación añadió que la contribución de la PTE en la autoestima está mediada por el lugar de control.

Discusión y conclusiones. Cuando los estudiantes creen que sus eventos son causados por su propio esfuerzo (que tiene lugar de la Línea de Control interno de la Línea de Control externo), el PTE no afectará a su autoestima. Mientras que el Inter-nal Línea de Control está relacionado con la responsabilidad, es posible proteger a los estudiantes la autoestima de la negativa influencia de TEP mediante la mejora de su sentido de responsabilidad, que a su vez los lleva a tener una antena interna Línea de Control. Por otra parte, el seguimiento de la investigación en la mejora de la Línea de Control interno se sugiere. Otras prácticas implicaciones de las conclusiones se discuten en el extremo del papel.

Palabras clave: estudiantes de alto rendimiento, locus de control, la esperanza de los docentes percibieron, la autoestima, la Teoría de la interacción simbólica, modelo bidimensional de la autoestima. 


\section{Introduction}

Symbolic interaction theorists maintained that self-esteem is significantly affected by individuals' perception of other people's expectancy, which are symbolized by overt behavior (Cooley, 1912; Coopersmith, 1967; Stryker, 2002). In the context of educational psychology, students evaluate themselves based on their perception of their teachers' expectancy, which is symbolized by the teachers' classroom behavior. Studies in various school settings have revealed that teachers tend to give more attention and academic supports to the high-performing students (HPS), and to control the attitude of low-performing students (LPS) in order to avoid disciplinary problems (Al-Fadhli \& Singh, 2006; Gamoran, 2002; Good, 1981; Tong, 2002). These differences elicit different perceived teachers' expectancy (PTE) between LPS and HPS (Hazri, Prihadi, \& Hairul, 2010), and subsequently contributes to their general self-esteem (Byrne, 1988; Jussim \& Harber, 2005), where HPS developed more adequate self-esteem than LPS (Prihadi, Hairul \& Hazri, 2010; Rubie-Davis, 2007). According to symbolic interaction theory, instead of being affected by teachers' actual expectancy, students' self-esteem is affected by their PTE, which derived from the teachers' classroom behavior they have observed. Furthermore, in previous studies, researchers tend to relate the students' self-esteem to their perceptions of teachers' expectancy (for example: Al-Fadhli \& Singh, 2006; Liu \& Wang, 2008; Prihadi et al, 2010; Tong, 2002; van Laar, 2000).

However, students in high-performance schools, where only HPS are accepted, might perceived their teachers' expectancy in different ways because they have different individual feelings about the placement of control and responsibilities over their events. This individual feelings, also called locus of control (LoC) (Rotter, 1966). LoC is a characteristic that determines whether individuals put the credits of their events to external causes such as other people, luck, fate, or internal causes such as one's individual efforts, abilities, or competence (Rotter, 1966, 1975, 1982, 1990). In other words, although there are some possibilities that students experience similar social attribution in high-performance schools, their personal differences in term of LoC may lead them to have their PTE influences their self-esteem differently. 
Studies in normal schools (where high, medium, and low-performing students are accepted) indicated that compared to the low-performing students (LPS), HPS possess significantly higher self-esteem (for example: Byrne, 1988; Prihadi et al., 2010; Rubie-Davis, 2007), even though LPS are not necessarily possess inadequate levels of self-esteem (van Laar, 2000). It was established that the perceived parental academic support affected the academic self-esteem of HPS in normal schools, while their LPS counterparts have it affected by the PTE (Liu \& Wang, 2008); which means that LPS tend to have external factor (other people's expectancy) affects their self-esteem, while HPS have their self-esteem influenced by internal factor. Nevertheless, for certain LPS, external LoC improve their self-esteem (van Laar, 2000) because when negative events take place in their lives, blaming external factors (discrimination, racism, school system, etc) prevent them from looking down at themselves. The latter two statements indicated that external attribution (or external LoC) contributed to the students' self-worth, which is one of the two dimensions of self-esteem after self-worth (Mruk, 2006).

Furthermore, supported by symbolic interaction theory, researchers tend to relate the students' self-esteem to their perceptions of others, such as teachers (for example: Al-Fadhli \& Singh, 2006; Liu \& Wang, 2008; Prihadi et al, 2010; Tong, 2002; van Laar, 2000). On the other hand, a research in high-performance schools, where only high-performing students (HPS) are accepted, offers a uniqueness of social environment compared to a normal school where HPS have LPS to be compared with. Student-teacher relationship in such schools might contribute differently to students' self-esteem. When LPS and HPS attend the same school, teachers' behavior is separated into two ways, where LPS perceived that they are expected to behave differently compared to HPS and vice versa (Hazri, et al., 2010), in a school attended by only HPS, variance of the students' self-esteem might not be iniciated by the perception of others' expectancy because students might perceive that they are expected similarly by the teachers.

Because LoC is a psychological trait that affect how an individual credit external factors (including other people's expectancy) upon their events (Rotter,1990), and LoC among students may vary albeit the identical academic achievements, this study will determine how LoC moderates the effect of students' PTE on general self-esteem (self-esteem) in a highperformance school setting. In addition, knowledge on how self-esteem is formed, together with how to maintain the self-esteem at an adequate level plays important role to help the students in facing future challenges and competitions, because excellent academic achievement 
without adequate self-esteem will lead them nowhere (Branden, 1969; Cigman, 2004; Ferkany, 2008; Kammeyer-Mueller, Judge, \& Piccolo, 2008; Lawrence, 2006).

It is important to note that this paper is not discussing the effects of academic performance on self-esteem or vice versa; therefore, global self-esteem is being investigated, instead of academic self-esteem. After all, the most important determinant of educational attainment is ability, thereby, it is not logical to expect general self-esteem to contribute large proportion of the variance of subsequent academic achievement scores (Slavin, 1990, 2006); In other words, self-esteem cannot be addressed as a major factor affecting academic achievement. However, this paper is written based on a belief that an adequate self-esteem is significant in determining students' future behavior and further success (Block \& Robbins, 1993; Ferkany, 2008; Humphrey, 2004; Kamayer-Mueller et al., 2008; Martin, Richardson, Bergen, Roeger, \& Allison, 2005; Von der Haar, 2005).

The following parts of this paper contain a brief about high-performance schools in Indonesia, followed by discussions about the influence of students' PTE on self-esteem, selfesteem among HPS, and the relationship between internal LoC and self-esteem. Methods and results of the study are discussed afterwards, followed by the practical implications and suggestions for future research.

\section{High-Performance Schools in Indonesia}

Several public high schools in Indonesia recently obtained a title of Internationally Standardized Schools, where most of the subjects are taught in English (Indonesian language is the common medium for public high schools in the country), and the students are periodically sent overseas for excursions (Pendidikan Network, 2009). In addition, only students with high academic achievement reports are accepted in such schools. Furthermore, unlike most of the public high schools in Indonesia and its surrounding countries, the internationallystandardized schools, do not practice ability-based tracking. It is expected by the educational stakeholders in Indonesia that students who graduated from such schools to be more competitive in international universities (Indonesian Ministry of Education, 2010). Related to that expectation, knowledge on maintaining self-esteem at an adequate level plays important role to help the students in facing future challenges and competitions (Kammeyer-Mueller, et al., 2008). 


\section{Influence of Students' Perceived Teachers' Expectancy on Self-Esteem}

Based on the finding of Oakes (1985) and Myers (2008), PTE can be divided into two categories. First, perception that teachers are expecting students to improve academic achievement (PTEa) and second, perception that teachers are expecting students to be potentially involved in disciplinary problems (PTEd). Previous studies discovered that teachers in normal schools have different expectancy towards HPS and LPS (Al-Fadhli \& Singh, 2006; Byrne, 1988; Tong, 2002). In schools where students were grouped based on academic reports, teachers were reported to expect HPS to be eager to improve academic achievement, and LPS would likely to have disciplinary problems (Oakes, 1985; Myers, 2008). Thus, information on previous academic performance affects teacher's expectancy; the expectancy then influences classroom behavior, which is obvious to the students.

Accordingly, Hazri et al. (2010) reported that HPS and LPS perceive their teachers' expectancy differently. HPS are likely to have significantly higher PTEa and lower PTEd compared to the LPS in normal schools. In other words, HPS tend to perceived that their teachers are academically supportive, and LPS tend to perceive that their teachers are trying to control their attitude in order to avoid disciplinary problems. Furthermore, Prihadi et al., (2010) discovered that the PTEd significantly affects the self-esteem of LPS ( $\beta=.17, p=.04)$, and HPS were significantly affected by their PTEa $(\beta=.21, \mathrm{p}=.01)$. Similar to what have stated by Jussim \& Harber (2005), the study also indicated that HPS possess significantly higher self-esteem than LPS ( $\mathrm{t}=1.984, \mathrm{p}=.048)$ and concluded that the variance of students' selfesteem is related to the variance of their PTE. It was obvious that HPS perceived that their teachers expected them to perform better than the LPS, because they were exposed to the existence of LPS in their schools, hence the stronger PTEa. Subsequently, their PTEa positively affected their self-esteem, as explained by the symbolic interaction theory (Coopersmith, 1967; Stryker, 2002).

\section{Self-Esteem among Students in High-Performance Schools}

It was stated that self-esteem is important to the motivation children need in order to be academically successful (Branden, 1994; Cigman, 2004; Ferkany, 2008; Lawrence, 2006; van Laar, 2000), and facilitating students' self-esteem might be a part that supports the schools' academic goals, without making it as an educational priority (Ferkany, 2008). On the other hand, self-esteem can be seen as a construct that mediates between ability and achieve- 
ment; self-esteem could influence subsequent achievement, and achievement could influence subsequent levels of self-esteem (Humphrey, 2004). Previous studies over decades indicated that in a school where students are grouped based on their abilities, self-esteem difference between HPS and LPS is significant (Al-Fadhli \& Singh, 2006; Byrne, 1988; Tong, 2002; Prihadi et al, 2010). In line with the suggestion of Mruk (2006), that individuals' self-esteem might be challenged when they face continuous rejection by the society, LPS in a streamed school tend to face some academic discriminations by being streamed in low-performing classrooms.

In addition, Mruk (2006) proposed the two-dimensional model that interprets selfesteem as the integrated sum of self-worth and self-competence. It means that in order to have positive self-esteem, a student must feel confident about both his/her sense of self-worth ('I am good and deserve to obtain care and respect from my peers and teachers') and his/her sense of self-competence ('I am able to meet the present and future challenges I face in life'). Based on Mruk's model, self-worth of HPS in a normal school is being supported by their being addressed as better than the LPS, and their self-competence is supported by their previous academic reports, which are obviously higher than the other students in the school. It is clear that HPS in high-performance school do not experience this previledge, because they do not have LPS counterparts to be compared to, hence their self-worth is not supported as much as it is in normal schools, although they can have their self-competence supported by their high previous academic reports.

\section{Students' Locus of Control and its Relationship to Self-Esteem}

The fact that individuals' internal or external LoC mediates their self-evaluation is in line with the view that reinforcement of any types did not have direct influence on an individual; it is the individuals' perception on reinforcement that mediated the relationship between the reinforcement and the behavior (Rotter, 1990). This view was supported by Ryckman few years later, who discovered that students who perceived that academic success was controlled by chance or fate relied less on their experiences in dealing with current behavior, studied less, and performed poorly than the students who perceived that academic success was determined by their own skills and competence (Ryckman, 1993). Statements by Rotter and Ryckman led to a belief that LoC mediates the effect of external influences on self-esteem in Symbolic Interactionists' points of view. 
Schunk and Pajares (2004) argued that internal LoC can be referred to self-efficacy, the belief that one can execute a specific course of action to achieve a goal (Bandura, 1989). Related to self-esteem, in Mruk's two-dimensional model, self-competence is also identical to the definition of self-efficacy by Bandura (1989). Thus, internal LoC is indeed related to selfesteem; individuals with internal LoC are likely to possess higher self-competence (Mruk, 2006), which is an important factor of the self-esteem.

Furthermore, it has been reported that students who are high in internal LoC have better grades and test scores than do students of the same intelligence, who are low in internal LoC (Capell \& Weinstein, 2001). Even though Slavin (2006) stated that in reality, students' success could be a product of both external and internal factors (abilities, efforts, task difficulty, teachers' behaviors, etc.), it was also reported that students' LoC is the second most important predictor (after ability) of a secondary school student's academic achievement (Bong, 2001; Pietsch, Walker, \& Chapman, 2003). The reason is that students who believe that academic success is due to luck, teachers' whims, or other external factors, are unlikely to work hard, while students who believe that their efforts determine their success can be expected to work harder. Nonetheless, Rotter (1966) argued that LoC is construed as a personality characteristic; thereby, identically high academic achievement will neither predict identically high self-esteem nor identical PTE.

Teachers' classroom behavior represents their expectancy towards the students (AlFadhli \& Singh, 2006; Good, 1981; Myers, 2008; Oakes, 1985; Tong, 2002), thus, teachers in high-performance school might show similar classroom behavior in front of every student. However, because LoC determines how an individual perceive the significance of others' expectancy (Duttweiler, 1984; Rotter, 1990), effects of students' PTE on their self-evaluation process will be mediated by their LoC. In other words, same teachers' behavior might elicit different PTE on different HPS, because they have different LoC. In turn, this difference will contribute to their self-esteem differences.

Another study reported that low internal LoC might lead to high self-esteem. Colette van Laar (2000) found that some Afro-American LPS can still possess adequately high selfesteem because they have external LoC. She maintained that these students did not have their self-evaluation affected by the fact that they scored academically low, because they believe 
that they were racially discriminated; they believed that white students will always reported to perform better than the Afro-Americans. Even though ethnicity is not the case in the context of this current study due to Indonesians' less sensitivity to such issues, other forms of discrimination might still be perceived by some HPS because the difference in their LoC determine the way they perceive their social environments.

Ryckman (1993), and Capell \& Weinstein (2001) reported that students with internal LoC have better grades and test scores than do students of the same intelligence, with external LoC. Therefore, students with internal LoC tend to have stronger self-competence, which leads to stronger self-esteem. The fact that individuals' internal or external LoC mediates their self-esteem is in line with the view that reinforcement of any types did not have direct influence on an individual; it is the individuals' way in perceiving reinforcement that mediated the relationship between the reinforcement and the behavior (Rotter, 1990). At this point, symbolic interaction theory is being confirmed.

Previous discussions lead to the research objective of this current study, which is to investigate how internal LoC mediates students' PTE on their self-esteem in a school environment where all of them are addressed as high-performers. Therefore, a question is to be answered: Is there any mediation effect of internal LoC on the causal effect of PTE and Selfesteem among high-performer students? Following the research question, null hypothesis to be tested is: There is no mediation effect of internal LoC on the causal effect of PTE and Selfesteem among high-performer students.

\section{Method}

\section{Participants}

Data were gathered on 800 high school students from a high-performance school in Surabaya, Indonesia, all of them are between 15-17 years old and were sitting in the first and second year during the data collection period. Each high-performance school in Indonesia contains approximately 1200 students, consisted of 400 students from first year, another 400 from second year, and another 400 from the final year. Due to some government's policy, data could not be obtained from the final year students.

\section{Instruments}


Students' self-esteem is measured by employing the Rosenberg's Self-Esteem Scale, RSES (Rosenberg, 1989), which considered as 'the gold standard' in self-esteem research (Miller \& Daniel, 2007). The scale is a 10-item self-report measure of global self-esteem. Originally five-point scales, the items are answered on a four-point scales (ranging from strongly agree to strongly disagree) in order to avoid the central tendency. Internal consistency of the questionnaire is assessed using Cronbach's alpha, and the instrument showed the reliability of .84

Students' LoC is measured by employing Internal Control Index, ICI, created by Patricia Duttweiler (1984). The ICI was developed based on the most pertinent variables to internal LoC construct such as cognitive processing, autonomy, resistance to influence attempts, delay of gratification, and self-confidence (Lefcourt, 1976).) It was suggested and validated that Duttweiler's scale is the most reliable and valid questionnaires in order to measure LoC in many cases (Furnham \& Steele, 1993; Meyers \& Wong, 1988). The ICI consists of 28 items with response alternatives that fall along 5-point scale from (A) 'rarely' to (E) 'usually'. The items were designed to drive highly internally oriented subjects (students with highly internal LoC) to answer half at the 'usually' end of the scale and answer the other half at the 'rarely' end of the scale. Internal consistency of the questionnaire is assessed using Cronbach's alpha, and the instrument showed the reliability of .88

Students' PTE is measured by using Perception of Teachers' Expectancy Scale, PTES. The scale was self-developed in 2009, based on the findings of Oakes (1985). PTBS is a 4 points scale with 20 survey items. Each engagement domain is represented by a subscale. There are 10 items for PTEa and PTEd constructs respectively. The students' response scale ranges from Strongly Disagree (=1) to Strongly Agree (=4). The internal consistency of the questionnaire was assessed using Cronbach's alpha and showed the score of .77.

\section{Procedures}

Back translation process has done in order to produce the Indonesian version of every single scale. All instruments were distributed to the students in bilingual version of English and Indonesian in order to enhance the comprehensiveness of each item. Under supervision of their teachers, students were given 2 hours to enter their answers.

\section{Statistical Analysis}


Figure 1 illustrated how the mediation effect is calculated. It is calculated by implementing four steps of regression equations (Baron \& Kenny, 1986) which can be defined as follows:

1. Finding the effect of the predictor on the criterion (path c)

2. Finding the effect of the predictor on the mediator (path a)

3. Finding the effect of the predictor and mediator on the criterion (path c')

4. Comparing the standardized regression coefficient $(\beta)$ of the path $\mathrm{c}$ and $\mathrm{c}^{\prime}$; if the $\beta$ in $\mathrm{c}$ is smaller, then the mediation occurs

In the context of this research, LoC is the mediator, PTE is the predictor, and selfesteem is the criterion (See Figure 1).

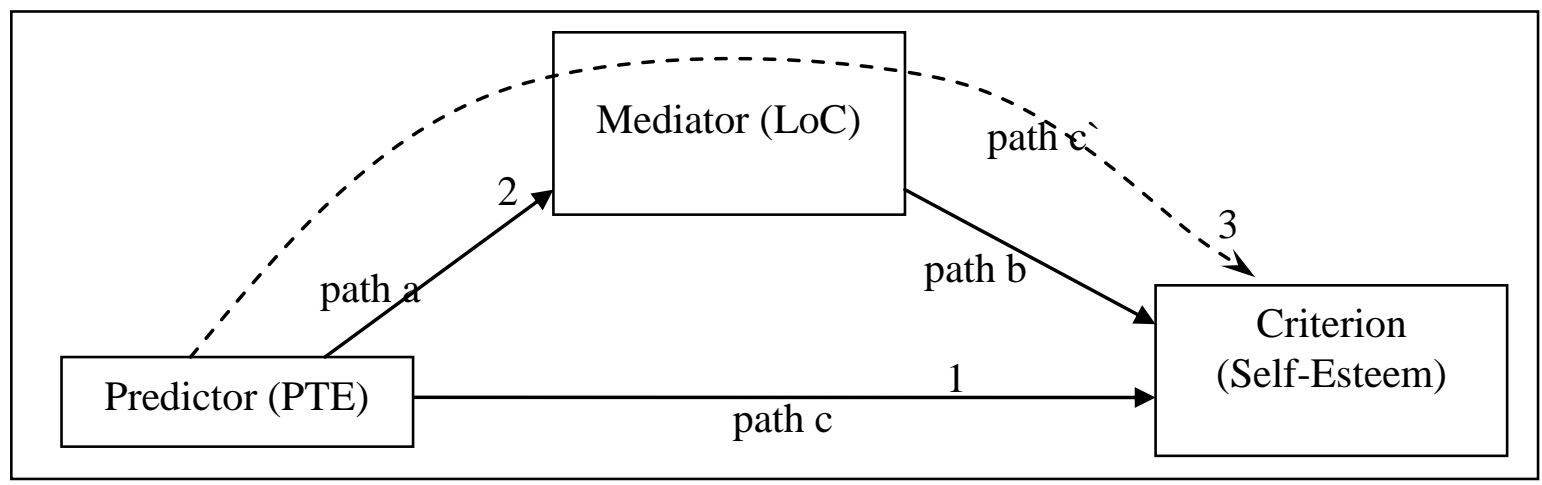

Figure 1. Mediating Model (Adopted from Baron \& Kenny, 1986)

Baron and Kenny (1986) suggested that the steps are stated in terms standardized regression coefficients $(\beta)$, instead of in terms of statistical significance; therefore, significance should not be taken into consideration. The reason was that trivially small coefficients can be statistically significant with large sample sizes and very large $\beta$ can be insignificant with small sample sizes. They maintained that statistical significance is informative, but other information should be part of statistical decision-making. They gave an example, in the case where path a is very large and path $\mathrm{b}$ is zero, thus $\mathrm{c}=\mathrm{c}^{\prime}$. It is possible that the statistical test of path $c^{\prime}$ is not significant (due to the collinearity between predictor and mediator), whereas path $\mathrm{c}$ is statistically significant. In that case, it would seem that there is a complete mediation when in fact there is no mediation at all. 


\section{Results}

Based on Figure 1, three statistical calculations (regression) were applied. First, the effect of PTE on Self-esteem, second, the effect of PTE on LoC, and third, the effect of PTE and LoC on Self-esteem.

\section{Effect of PTE on Self-esteem}

In the analysis process, the stepwise method entered only one of the predictor variables, which is PTEd. The variable PTEa was not entered because its F score is neither lower than .050 nor higher than .100 (See Table 1). In Table 2, it is indicated that the PTEd of HPS could explain $12.5 \%$ of the variance in their self-esteem (Adjusted $\mathrm{R}^{2}=.125$ ), and the test is significant because the $\mathrm{p}$ score is .000 (See Table3). Table 4indicates that the $\beta$ value of the PTEd is -.357, which means that the influence of PTEd on the self-esteem of HPS was negatively directed and strong (greater than .20)

Table 1. Variables Entered/Removed

\begin{tabular}{|c|c|c|c|}
\hline Model & Variables Entered & Variables Removed & Method \\
\hline 1 & PTEd & & $\begin{array}{l}\text { Stepwise (Criteria: Prob- } \\
\text { ability-of-F-to-enter <= } \\
.050, \text { Probability-of-F-to- } \\
\text { remove }>=.100) \text {. }\end{array}$ \\
\hline
\end{tabular}

Table 2. Model Summary of LAC students' PTEd on their self-esteem

\begin{tabular}{lrrrrr} 
Model & R & R Square & Adjusted R Square & Std. Error of the Estimate \\
\hline 1 & $.357^{\mathrm{a}}$ & .127 & .125 & .46028 \\
\hline
\end{tabular}

Table 3. Analysis of Variance, the HAC students' PTEd on their self-esteem

\begin{tabular}{llrrrrr} 
Model & & Sum of Squares & df & Mean Square & F & Sig. \\
\hline 1 & Regression & 10.724 & 1 & 10.724 & 50.619 & $.000^{\mathrm{a}}$ \\
& Residual & 73.513 & 347 & .212 & & \\
& Total & 84.237 & 348 & & & \\
\hline
\end{tabular}


Table 4. Coefficients of HAC students' PTEd and their self-esteem

\begin{tabular}{|c|c|c|c|c|c|c|}
\hline \multirow[b]{2}{*}{ Mode } & & \multicolumn{2}{|c|}{ Unstandardized Coefficients } & $\begin{array}{l}\text { Standardized } \\
\text { Coefficients }\end{array}$ & \multirow[b]{2}{*}{$\mathrm{T}$} & \multirow[b]{2}{*}{ Sig. } \\
\hline & & B & Std. Error & Beta & & \\
\hline \multirow[t]{2}{*}{1} & (Constant) & 4.275 & .160 & & 26.640 & .000 \\
\hline & PTEd & -.504 & .071 & -.357 & -7.115 & .000 \\
\hline
\end{tabular}

Based on the Table 1, 2, 3, and 4, it can be concluded that the students in the PTEa of HPS does not play significant role in predicting their self-esteem because it is not entered by the stepwise method. On the other hand, their PTEd significantly and strongly affects their self-esteem, and the direction of the influence is negative. It means that the more they perceive that their teachers are trying to control their behavior, the lower their self-esteem will be.

\section{Effect of PTE on LoC}

In the analysis process, enter method is being used due to its capability to keep calculating the results regardless the insignificance. In other words, although neither PTEa nor PTEd significantly affect the LoC of the HPS, significance is not taken into consideration in calculating the mediating effect (Baron \& Kenny, 1986). Table 5 depicts the analysis results. As shown in Table 5, The $\beta$ value of the PTEa and PTEd are -.015 and -.011 respectively.

Table 5. Coefficients of HPS' PTE and their LoC

\begin{tabular}{llrrrrr}
\hline & & \multicolumn{5}{c}{ Standardized } \\
Unstandardized Coefficients & Coefficients & & \\
\cline { 3 - 5 } Model & & B & Std. Error & Beta & \multicolumn{1}{c}{ t } & \multicolumn{1}{c}{ Sig. } \\
\hline 1 & (Constant) & 2.895 & .208 & & 13.943 & .000 \\
& PTEa & -.014 & .050 & -.015 & -.274 & .784 \\
& PTEd & -.015 & .074 & -.011 & -.208 & .835 \\
\hline
\end{tabular}

\section{Effect of PTE and LoC on Self-esteem}

The Mediation effect of both PTEa and PTEd are calculated. Table 6 and Table 7 depict the summary of the previous calculations. 
Table 6. Mediation of LoC on the influence of PTEd on self-esteem among HPS

\begin{tabular}{|c|c|c|c|c|}
\hline Equation & $\begin{array}{c}\text { Adjusted } \\
\mathbf{R}^{\mathbf{2}} \\
\end{array}$ & $\begin{array}{l}\text { Std. } \\
\text { Error }\end{array}$ & $\beta$ Value & Significance \\
\hline 1 PTEd on self-esteem & .125 & .0460 & -.357 & .000 \\
\hline 2 PTEd on LoC & -.003 & & -.014 & .800 \\
\hline 3 PTEd \& LoC on self-esteem & .131 & .459 & $\begin{array}{cc}\text { PTEd } & \text { LoC } \\
-.356 & .093\end{array}$ & $\begin{array}{cc}\text { PTEd } & \text { LoC } \\
.000 & .064 \\
\end{array}$ \\
\hline
\end{tabular}

Table 7. Mediation of LoC on the influence of PTEa on self-esteem among HPS

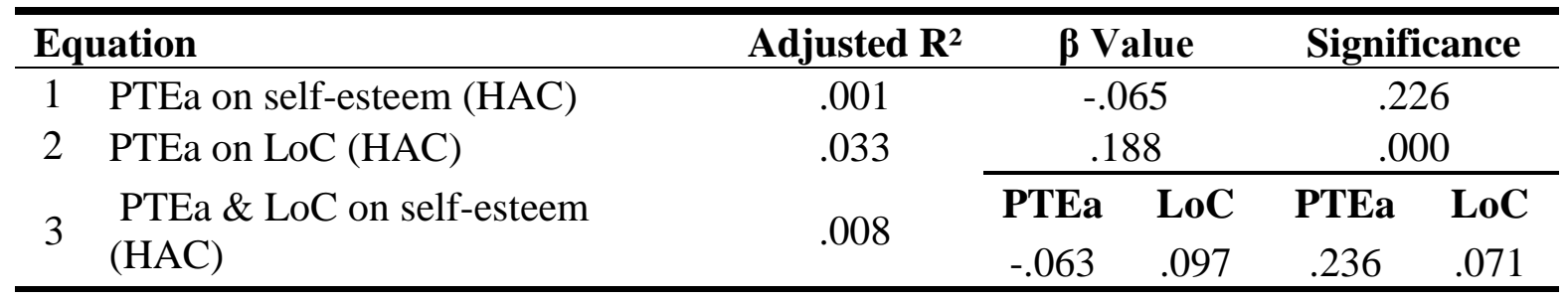

As shown in Table 6 , the $\beta$ (beta value) of PTEd in equation 3 shows smaller value (.356) than in equation 1 (-.357), and both of them are significant. In quotation 1 , the PTEa explained $12.5 \%$ of the self-esteem variance and with LoC included, the proportion of explained variance increased to $13.1 \%$. Therefore, LoC partially mediates the influence of PTEd on the self-esteem among HPS. Furthermore, in Table 7, it is shown that the $\beta$ value of the PTEa in equation 3 (-.063) is smaller than the one in equation 1 (-.065). In quotation 1 , the PTEa explained only $0.1 \%$ of the self-esteem variance; with LoC included, the proportion of explained variance increased to $0.8 \%$. It can be concluded that LoC partially mediates the influence of PTEa on the self-esteem among HPS. Thus, the null hypothesis is rejected.

\section{Discussion and conclusions}

It is indicated that once the students credit themselves for their academic results and successes, they will not rely on their perception of teachers' expectancy in evaluating themselves. Symbolic interaction theory might explain this phenomenon; being accepted in highperformance schools led the students to perceive that the teachers would put equally high academic expectancy on each student, thus their PTEa did not predict self-esteem, because being expected to achieve high is perceived as a common attribute among the students. On the other hand, their PTEd predicted their self-esteem significantly in a negative way, and able to explain $35.7 \%$ of the self-esteem variance $(\beta=-.357 ; p=.000)$. It means that when they perceived that their teachers expected them to be involved in disciplinary problems, their self-esteem is 
reduced. However, the fact that LoC mediated the causal relationship between PTE and selfesteem showed that the influence of PTE on the self-esteem was depending on their LoC. In other words, they will not use their PTE to evaluate themselves had they have strong internal LoC.

Theoretically, related to the two-dimensional model of self-esteem (Mruk, 2006), selfworth of HPS is being elevated by the situation that their perception that they are expected to achieve high; and their self-competence is being represented by their internal LoC. Therefore, findings of this study might not confirm the Symbolic Interaction Theory (Coopersmith, 1967; Stryker, 2002), which maintained that self-evaluation (self-esteem) is determined solely by the individuals' perception of other people's expectancy.

In the context of this study, it is discovered that perception of teachers' expectancy is depending on how the students credit the teachers' role in the students' events. However, findings of this study do not negate the previous reports on significant influence of PTE on self-esteem (Al-Fadhli \& Singh, 2006; Byrne, 1988; Tong, 2002; Hazri et al., 2010; Prihadi et al., 2010). That was because of two reasons: (1) LoC was not involved in those studies as moderating variables; and (2) other studies have done in normal schools, where teachers' expectancy might be affected by the different features of HPS and LPS, and it might lead to different PTE among HPS and LPS.

Findings of this current study can be summarized as the stronger the internal LoC, the higher the self-esteem of HP. On the other hand, van Laar (2000) discovered that the stronger the external LoC, the higher the self-esteem of LPS. Possessing external LoC, LPS in van Laar's study attributed racial discrimination (external factor) for their low academic achievements, and did not have their self-competence and self-worth challenged, hence the adequately high self-esteem. On the other hand, possessing internal LoC, samples in this current study rely more on internal attribution than external factors (such as teachers' expectancy) in evaluating themselves.

Related to Mruk's two-dimensional model of self-esteem (Mruk, 2006), van Laar's LPS did not feel that their low academic results were caused by their lack of competence. HPS in this current study credited themselves for their high academic results; therefore, they feel that the good results were caused by their own competence. Therefore, it can be hypothe- 
sized that LPS with external attribution might possess equally high self-esteem to HPS with internal attribution. However, another research in all-LPS schools should be done in order to test the hypothesis.

Although this research has done in an exclusively-HPS school, similar phenomenon might as well be found in streamed or tracked schools. In such school, a classroom would be attended exclusively by HPS or LPS, and this situation might create similar (but not identical) environmental influence to the students. Even though students in high-performance school do not have other schoolmates to be addressed as 'weaker', the general society will address them as HPS in a bigger social context (city, region, country), therefore they might still have some perceptions that they are expected to achieve higher than the others.

Nonetheless, some differences might occur between students from high-performance schools and HPS in a school that practices ability grouping or tracking. The latter might have no significant PTEd, because they perceive that their teachers will not expect them to be 'bad' due to the presence of LPS at the other end of the batch. They might likely to have more significant PTEa, because they perceive that teachers do not expect LPS in other classrooms to achieve as high as them (Hazri, et al., 2010; Prihadi, et al., 2010). In this situation, their internal attribution might not mediate the effect of PTEa on their self-esteem, and their PTEb will not predict their self-esteem at all. Accordingly, Liu \& Wang (2008) established that the perceived parental academic support affected the academic self-concept of HPS in streamed schools, while their LPS counterparts were affected by PTE. Even though the role of internal LoC in the latter statement was vague, their statement indicated that HPS in streamed schools did not rely on their PTE in order to appraise themselves academically.

\section{Future Research}

Limitation of this current study is that it has done in an exclusively HPS schools. The result could be vary when similar research is done in normal streamed schools, normal schools that practices mixed ability grouping, or exclusively LPS schools. This current study has done on high school students between 15-16 years old, therefore the students might already have had their self-esteem developed before entering the high school. Researches on younger students group might as well be conducted due to some possibilities of different results. Other traits, such as gender, intelligence quotient, and types of motivation might as well be involved in developing the students' general self-esteem related to their LoC and PTE. 
Another limitation is the absence of the other external factors of students' general selfevaluation, such as perceived parental academic supports, perceived school climate, academic self-concept, or social economic status. Future research should be conducted in order to investigate how the students' LoC mediates the effect of mentioned external factors on general self-esteem. In other words, there is a gap of literature on how internal factors (such as LoC) mediate the effect of external factors on general self-esteem, especially in educational context. Thereby, future researches should be conducted to fill the gap. Finding of such researches might be significant in determining more effective methods on developing students' general self-esteem.

Sequentially, researches on finding effective methods to improve students' internal LoC is significant to elevate students' self-esteem and academic achievement. However, because LoC is a culture-sensitive trait (Ji, Peng, \& Nisbett, 2000), different cultural settings might produce different results. Therefore, following another limitation of this study that all of the students came from the same cultural background, studies on multi-cultural schools (such as international schools) or cross-cultural studies, are as well suggested.

\section{Practical Implications}

Related to the statements that facilitating students' self-esteem should be a part of schools' academic goals (Branden, 1994; Cigman, 2004; Ferkany, 2008; Lawrence, 2006) due to its being important to students' motivation and future success (Ferkany, 2008; Önder, Kurdök, \& Işik, 2010; Slavin, 2006; van Laar, 2000), it is suggested that different type of schools to have different strategies in enhancing students' self-esteem. In high-performance schools, students' internal LoC plays significant role in determining their self-esteem, and internal LoC is related to the self-competence in two-dimensional model of self-esteem (Mruk, 2006); therefore, improving students' self-worth, might not be a very effective strategy to improve students' self-esteem in an exclusively-HPS school. In order to improve their self-competence, a different strategy can be applied, such as consistently reminding them that they are academically competent and their academic achievement is the result of their own effort.

Practices that indicate students' dependency to the teachers (such as emphasizing teachers' authority in the classrooms) should be avoided without reaching to an extent where the students lost their respect to the teachers. However, cultural aspects should be carefully 
considered in applying this kind of strategy, because the borderline of being academically independent and being disrespectful might be different in some cultures. Another important note to take is that the extremely internal or extremely external LoC predict low self-esteem score (Schwartz \& Kaslow, 2000), which will harm the students' future. Internal LoC of their students should be kept in adequate levels, therefore they will not blame themselves too much over insignificant failures, which will decrease their self-competence even further.

On the other hand, in normal schools teachers are likely to have different expectancy towards LPS and HPS (Good, 1981; Oakes, 1985; Rubie-Davies, 2007), which is observable for the students through teachers' classroom behavior (Hazri et al., 2010; Jussim \& Harber, 2005), and in turn, students' PTE predicts their self-esteem (Al-Fadhli \& Singh, 2006; Byrne, 1988; Prihadi et al., 2010; Tong, 2002). It is suggested to avoid the ability-based discriminative behavior that might ellicit different PTE among the students; teachers should deliberately show their academic support to all students in order to let the them develop higher PTEa and lower PTEd. In turn, PTEa will improve the self-worth of the LPS, and their self-esteem in general. It is important to note, however, that some studies reported the significance of internal LoC in determining academic achievements (Bong, 2001; Pietsch, Walker, \& Chapman, 2003), therefore, any strategy to improve the internal attribution should not be applied exclusively to HPS; there are some possibilities that LPS might improve their academic achievement when their internal LoC is improved.

Improving students' internal LoC could be one of the practical implications to improve the students' self-esteem and to maintain it in adequate levels. It can be done by consistently reminding the students that they are academically competent and their academic achievement is the result of their own efforts. Another strategy is to minimize any practice that indicate students dependency to the teachers (such as emphasizing teachers' authority in the classrooms), without reaching to an extent where the students lost their respect to the teachers.

Nevertheless, the practice of the latter strategy requires mutual understanding among school managements, teachers, and students on the borderline of being academically independent and being disrespectful. Similar strategies might be applied to normal schools where teachers tend to have different expectancy towards LPS and HPS (Good, 1981; Oakes, 1985; Rubie-Davies, 2007). Because HPS are likely to have PTEa and LPS tend to have PTEd, teachers in normal schools should be aware that PTEa elevates students' self-worth and PTEd 
decreases it. It is suggested to avoid the ability-based discriminative behavior that might ellicit PTEd; teachers should deliberately show their academic support to all students in order to let them develop higher PTEa and lower PTEd. In turn, PTEa will improve the self-worth and their self-esteem in general. 


\section{Acknowledgements}

This research is supported and sponsored by the fellowship program from Institute of Postgraduate Studies, Universiti Sains Malaysia.

\section{References}

Al-Fadhli, H., \& Singh, M. (2006). Teachers' expectancy and efficacy as correlates of school achievement in Delta, Mississipi. National Evaluation Institute Conference. Dallas: National Evaluation Insitute Conference.

Bandura, A. (1989). Human agency in social cognitive theory. American Psychologist , 44, 1175-1184.

Baron, R. M., \& Kenny, D. A. (1986). The Moderator-Mediator Variable Distinction in Social Psychological Research: Conceptual, Strategic, and Statistical Considerations. Journal of Personality and Social Psychology, 51 (6), 1173-1182.

Block, J., \& Robbins, R. (1993). A longitudinal study of consistency and change in selfesteem from early adolescence to early adulthood. Child Development , 64, 909-923.

Bong, M. (2001). Between-and within-domain relations of academic motivation among middle and high school students: Self-efficacy, task-value, and achievement goals. Journal of Educational Psychology, 93 (1), 23-24.

Branden, N. (1969). The psychology of self-esteem. New York: Bantam .

Byrne, B. M. (1988). Adolescent self-concept, ability grouping, and social comparison: reexamining academic track. Atlanta: American Psychological Association.

Capell, E., \& Weinstein, R. (2001). Turning around reading achievement: Predictors of high school students' academic resilience. Journal of Educational Psychology , 93 (4), 758771.

Cigman, R. (2004). Situated Self-Esteem. Journal of Philosophy of Education, 38, 91-105.

Cooley, C. (1912). Human Nature and the Social Order. New York: Scribners.

Coopersmith, S. (1967). The Antecedents of Self-Esteem. San Francisco: Freeman.

Duttweiler, P. C. (1984). Internal control index: a newly developed measure of locus of control. Educational and Psychological Measurement , 44 (2), 209-221.

Education, I. M. (2010, May 4). kebijakan sekolah bertaraf internasional. Retrieved March 21, 2011, from Kementrian Pendidikan Indonesia: http://mendikdasmen.kemdiknas.go.id/docs/Kebijakan-SBI.pdf 
Ferkany, M. (2008). The educational importance of self-esteem. Journal of Philosophy of Education , 42 (1).

Gamoran, A. (1992). Is ability grouping equitable? Chicago: EBSCO Publishing.

Good, T. L. (1981). Teacher's expectancy and students' perception: a decade of research. Educational Leadership , 38 (5), 415-422.

Hazri, J., Prihadi, K., \& Hairul, N. I. (2010). Students' Perception of Teachers' Behavior in the Classrooms: Effect of between-class ability grouping practice in Malaysia. Journal of Applied Research in Education, 14, 87-94.

Humphrey, N. (2004). The Death of the Feel-Good Factor? : Self-Esteem in the Educational Context. School Psychology International , 25 (3), 347-360.

Humphrey, N. (2004). The Death of the Feel-Good Factor? : Self-Esteem in the Educational Context. School Psychology International , 25, 347-360.

Jussim, L., \& Harber, K. (2005). Teacher expectations and self-fulfilling prophecies: Knowns and unknowns, resolved and unresolved controversies. Personality and Spcial Psychology Review , 9, 131-155.

Kammeyer-Mueller, J. D., Judge, T. A., \& Piccolo, R. F. (2008). Self-Esteem and Extrinsic Career Success: Test of a Dynamic Model. Applied Psychology, 57 (2), 204-224.

Lawrence, D. (2006). Enhancing Self-Esteem in the Classroom. London: Paul Chapman Publishing.

Liu, W. C., \& Wang, C. K. (2008). Home Environment and Classroom Climate: An Investigation of their Relation to Students' Academic Self-Concept in a Streamed Setting. Current Psychology, 27, 242-256.

Martin, G., Richardson, A., Bergen, H., Roeger, L., \& Allison, S. (2005). Perceived academic performance, self-esteem and locus of control as indicators of need for assessment of adolescent suicide risk: implications for teachers. Journal of Adolescence , 28 (1), 75 87.

Mruk, C. (2006). Self-Esteem Research, Theory, \& Practice, 3rd edition. New York: Springer Publishing Company.

Myers, D. G. (2008). Social Psychology. Holland, MI: McGraw Hill.

Oakes, J. (1985). Keeping Track: How Schools Structure Inequality. New Haven, CT: Yale University.

Önder, F., Kurdök, O., \& Işik, E. (2010). High school students' career decision-making pattern across parenting styles and parental attachment levels. Electronic Journal of Research in Educational Psychology, 8 (1), 263-280. 
Pendidikan Network, I. (2009, April 6). References Pendidikan Network Indonesia. Retrieved March 21, 2011, from Berita Pendidikan: http://beritapendidikan.com/mod.php?mod=publisher\&op=viewarticle \&cid=12\&artid=1533

Pietsch, J., Walker, R., \& Chapman, E. (2003). The relationship among self-concept, selfefficacy, and performance in mathematics during secondary school. Journal of Educational Psychology , 95 (3), 589-603.

Prihadi, K., Hairul, N. I., \& Hazri, J. (2010). Students' Self-Esteem and their Perception of Teacher Behavior: A Study of Between-Class Ability Grouping. Electronic Journal of Research in Educational Psychology, 8 (2), 707-724

Rotter, J. B. (1966). Generalized Expectancies for Internal versus External Control of Reinforcement. Psychological Monographs , 80 (1), 1-28.

Rotter, J. B. (1975). Some problems and misconceptions related to the construct of internal versus external control of reinforcement. Journal of Consulting and Clinical Psychology (43), 56-67.

Rotter, J. (1990). Internal versus external control of reinforcement: A case history of a variable. American Psychologist (45), 489-493.

Rotter, J. (1982). Social learning theory. In N. Feather, Expectations and actions: Expectancyvalue models in psychology (p. 2443). Hillsdale, New Jersey: Lawrence Erlbaum Associates, Publishers.

Rubie-Davies, C. M. (2010). Teacher expectations and perceptions of student attributes: Is there a relationship? The British journal of educational psychology , 80 (1), 121-135.

Ryckman, R. (1993). Theories of personality. Pacific Grove, CA: Brooks/Cole Publishing Company.

Schunk, D., \& Pajares, F. (2004). Self-Efficacy in Education: Issues and future directions. Paper presented at the annual meeting of the American Educational Research Association. San Diego, CA.

Schwartz, J., \& Kaslow, N. (2000). Psychological, cognitive, and interpersonal correlates of attributional change in adolescents. Journal of Clinical Child Psychology , 29 (2), 188198.

Slavin, R. E. (1990). Achievement effects of ability grouping in secondary schools: A best evidence synthesis. Review of Educational Research, 60, pp. 471-499.

Stryker, S. (2002). Symbolic Interactionism: A Social Structural Version. Caldwell, NJ: Blackburn Press. 
Tong, H. S. (2002). A Comparison of the perception of teachers assigned to teach higher and lower ability group. Hongkong: University of Hongkong.

van Laar, C. (2000). The Paradox of Low Academic Achievement but High Self-Esteem in African American Students:An Attributional Account. Educational Psychology Review, 12 (1), 33-61.

Von Der Haar, C. M. (2005). Social Psychology: A Sociological Perspective. Upper Saddle River, NJ: Pearson Education. 